\title{
New Notes on some Old Inscriptions.
}

By Charles C. Torrej.

\section{Byblos.}

Lines ro-13. I believe that the text of these lines, which is missing in part, and has given a great deal of trouble to its interpreters, can be restored with a considerable degree of probability.

The restoration of the beginning of line so makes no difficulty. For the end of the line, and the lost beginning of line II, we may restore and read as follows: ris]

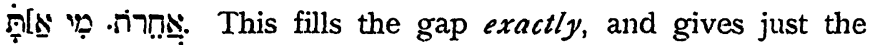
sense which the context suggests. The reading $\square \underline{\text { is de- }}$

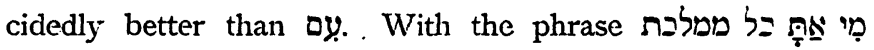
ובל אדם , beginning the next main division of the inscription, compare the same phrase, or closely similar phrases, in Tabnit (line 3), Ešmūn'azar (lines 4, 20), the two Nèrab inscriptions (꼬 in $I_{5}$ and $I I 8$ ), and the Guzneh Boundary Stone (דָ the word $\mathrm{N}$ seems to be visible at the broken beginning of the line. In the middle of the line, the facsimile suggests ף rather than

The restoration of the missing beginning of line 12 has never made any difficulty. The only doubt can be as to the demonstrative pronoun after [מומ be $i$ or $i$; either is possible. 
The word 0 , which occurs in line 12 and again in line 13 , has always been interpreted as active participle of the verb $ם$ ie, and the lines have been regarded as containing imprecations. But this interpretation raises insurnountable obstacles at once, and the lines have gencrally been abandoned as hopeless. It has been taken for granted that the king, who is dedicating these votive objects and the building which he has constructed, is cursing any successor of his who shall add to the work or alter it in any way. But is it not at least as likely that he is saying, as so many others in similar circumstances have said: "This is $m y$ work. If any one in the future adds to it or changes it, it is still my work; and the credit for it must be given

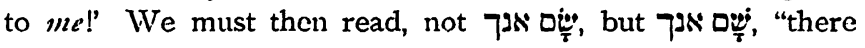
am I!" It is the very same thing which Ašurbanapal, for example, says in one of his inscriptions which is repeated in several different forms (see the Keilinschriftliche Bibliothek II 234, 260; Lron, Assyrian Manual 24, lines ${ }_{4}$ ff., etc.). After speaking of the works which he had completed and dedicated, the king proceeds: "Whenever, in the future, any king or high official ${ }^{\mathrm{x}}$ ) shall renew or repair this work; if he leaves my name upon it, anointing it (i. e. the document) with oil, and offering sacrifice, and adding his own name, then will the great gods hear his prayers. But if he shall destroy or remove my name, then may the great gods name my name for his condemnation, and destroy his name and his seed forever." ${ }^{2}$ ) The gap at the beginning of line 13 is then to be filled as follows: שָָׁם אנךך יחומלך [מלך גבל ויאנך] פעל מלאבת הא.

The word אבמל, in the middle of the line, is pretty certainly the emphatic double negative, $b_{2} \cdots$, and the verb

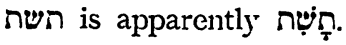

I) One of the texts has sarru, and another rubü.

2) I have given freely the substance of the texts, not translating any single one exactly. 
The whole passagc might be translated as follows: And may to [the Lady, M]istrcss of Gebal, give [him] favor in the sight of the gods, and in the sight of the people of this land, and the favor of the people of " [other] lan[ds].

Whosoever thou art, prince or man, zeho doest furthe, work on [this] 12 al[tar, or on] this [cngrav]ed-work(i) of gold, or on this portico, there am I, Yehawmelek, ${ }^{13}$ [king of Gebal, and I am] the doer of that work. Or if thou put (here) nothing at all, there am I. And if . . . .

What follows is too fragmentary for any satisfactory restoration.

\section{Tabnit.}

In lines $3-5$, the finder of the sarcophagus is urged not to open it, and it is said that no silver, nor gold, nor jewels have been buried in the coffin with the king. The

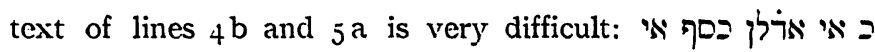
ארלן חרץ ובל מן ממשר. With this passage must be compared,

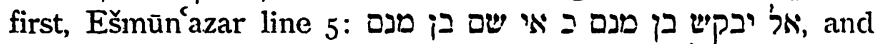

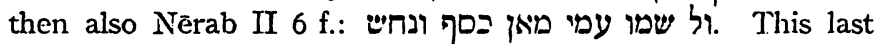
passagre is to be translated, obviously, "And they did not put (i. e. bury) with me any vessel (or, ornament?) of silver or bronze". The Ešmūn'azar passage: "Do not seek here(?) jewels, for no jewels are deposited here". (The gencra! meaning of ${ }^{2}$, "with me" or "in it" or "here", is certain, though the form itself is of uncertain origin. As for $\square$, it

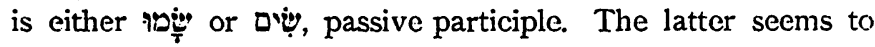
me preferable, the singular number being unobjectionable.) In the Tabnit passage, finally, there are two very trouble-

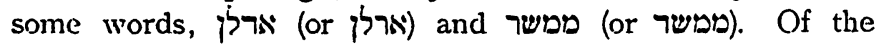
former, it is sufficient to say now that it corresponds to in the Ešmun'azar passage; that is, it is, in the sentence, at least a rough equivalent of an adverb of place, "here". ${ }^{x}$ )

1) I do not mean by this to imply anything as to its composition. I 
But it is the latter part of the phrase, ובלמנממשi, that calls for special attention. First comes $\$=$ ?, beyond any doubt. What romains has always (so far as I am awarc) been divided מנם משi But after $ל=$, in this negative clause, the plural number is not to be expected, according to Semitic usage; the noun following must be singular, that is, 棺. This lcaves what appears to be a participle (presumably piial or hof'al), ממשר. The only plausible ctymology which suggests itself is the one obtained from the very common Assyrian verb mušsur, meaning "leave, leave bchind", etc.

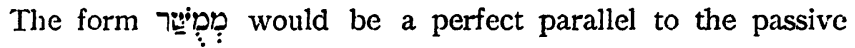
participle ب̣ in the corresponding phrase of the Ešmūn'azar inscription. The logical connection of the word would then

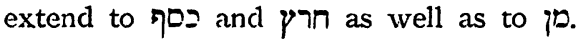

In the serenth line of the inscription occurs the phrase אל ינל זרע בחים. It is customary ${ }^{2}$ ) to substitute for ינל two words ${ }^{\prime} i=$, on the supposition that the engraver omitted twice(!) by accident the letter $:$; compare Ešmūn'azar, line 8, אל ירן לם. This is desperate treatment, indeed. An engraver might easily omit the letter once; but against its omission twice within the space of four letters the chances are almost infinite. The letter is a very easy one to carve, and there was abundant space. Whether by is supposed to be defective, or not, we can be quite certain of this, that the reading originally intended was not

The reasons for dissatisfaction with the reading ינל two in number: (1) the difficulty of connecting it with any known North-Semitic root; and (2) the supposed necessity

would suggest, however,' that the first element in the compound might be

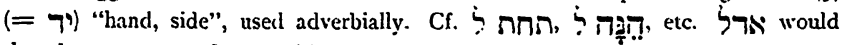
then be a compound preposition.

I) So, for example, Cooke, North Sem. Inscriptions; Lidzb.1RSki, Handbuch, and Altsem. Texte; LANDAU, Beiträge aur Altertumskunde des Orients II, p. 6. 
(or desirability) here of a clause containing the second person rather than the third. But noither reason is justified. A suitable etymology, well supported, is to be had; and as for the third person, I shall show that it is the one to be expected here.

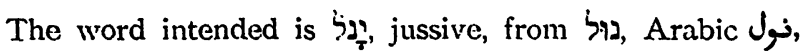
"take, obtain". The verb is a very common one in Arabic, but only a few traces of its use in the North-Semitic dialects have survived. In Syriac we have only the verb $\vec{\Delta} \vec{u}$, "torment", whose connection with the original root is, moreover, quite uncertain. Nö.DEkE, Neue Beiträge zur semitischen Sprachevisscnschaft (1910), p. 216, in spcaking of the Talmudic word נִּאלא (an evil spirit), says: "Das Wort ließc

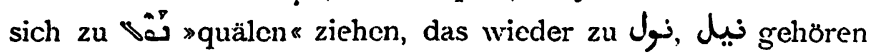
wird, als dessen Grundbedeutung etwa "greifen, packen" anzusehen wäre." But we have much older and more direct testimony than this. In Ezra 6: i , Dan. 2: 5, 3: 29, occurs the phrase ביתה נולו יתעבד, "his house shall be made a

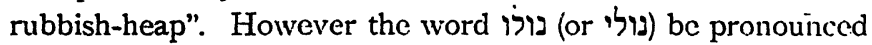
and interpreted, it is very important to observe that the old Greek translator (or translators) ${ }^{x}$ ) derived it from נוף meaning "take possession". I Esdr. 6: 31 gives xai $\tau \dot{a}$ vंráoyourca

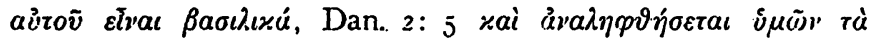

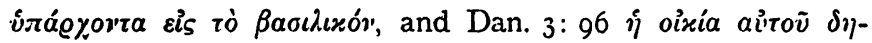
$\mu \varepsilon v \vartheta \eta$ joetal. These renderings, taken in connection with our passage in the Tabnit inscription, are enough to prove the use of the root in the Syro-Palestinian dialects.

As for the change from the second person to the third, this is simply due to the imprecation. The feeling was always strong in the Semitic Orient that the second person ought to be avoided, so far as possible, in passages containing curses or other expressions of ill omen. It would be

1) As I have shown in my Ezra Studies, the old Greek versions of Daniel and Ezra ("I Esdras") were made in the middle of the second century li.C. See especially pp. 82 f., 84 f.

Zeitscbr. I Assyriologie, XXVI. 
('isy (1) multiply illustrations here, but the subject has becn treated in many places. Sec especially Gotmzmine, Abhandlungen zur arabischen Philolngic I, 38-41; J.Axk, Thousand and One Nights I, 117 (note 8); MERX, Die vier kanonischen Evangclien 1. 235, note; LEVY, Lexicon s. v. 'j:. Hence, for example, thic public reader of the Hebrew scriptures read l.ev. $18: 7 \mathrm{ff}$. with the substitution of suffixes of the third person for those of the second. (Notice also the striking change of person in II Chron. 7:20.) And hence in Matt.

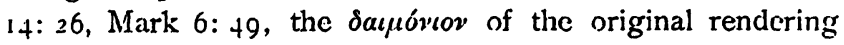
was altered to the harmless pávtaoua. ') In inscriptions of approximately the age of Tabnit we find the very same change, from second person to third, occurring at the point where the curse begins. Thus Nèrab II, lines $8 \mathrm{f}$.: "Whosocver thou art that shalt injure (second person) . . . ., may Sahar and Nikal and Nusk make his death shameful!" ${ }^{2}$ ) So also the Guzneh Boundary Stonc ${ }^{2}$ ): "Whosoever thon art ....., may (the gods) destroy him and his seed!" Also at the end of the Byblos inscription, in spite of the present mutilation it is quite certain that the same change of persons takes place, and for the same reason. ${ }^{3}$ ) Another example, from a later day, is furnished by the Syriac inscription published in LIDzBarskI, Handbuch, 484, 3 . In Nērab I, lines $10 \mathrm{f}$., the second person is indeed retained in the imprecation (as of course would occasionally happen). There, however, the case is somewhat different, inasmuch as the curse is immediately followed by a blessing invoked on the

1) So the Lewis Syriac text proves conclusively. It is not at least ex-

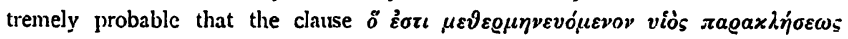
was inserted in Acts $4: 36$ for a similar reason? The origin of the name Barnabas (Sun of Nabū, Nebo) was of course perfectly well understood. Why, otherwise, should the interpretation(!) of the name have been given at all?

2) Regarding the text of this, see further below, p. 90 .

3) The condition, introduced by a verb in the second person, begins at the end of line 13. The conclusion, which therefore must have contianed a curse, was expressed in the third person, as is scen in the last words of line 15. 
one (addressed also in the second person) who spares the tomb.

The translation of lines $3 \mathrm{ff}$. : Whatever man thou art, who findest this coffin, do not in any wise ${ }^{4}$ open (it) upon me, nor disturb me; for with me is no silver, with me is no s gold, nor any ornament, deposited. ..... And if thon shalt in any 7 wise open (it) upon me, or in any zeise disturb me, - may he obtain no sect among the living; under the sun, ${ }^{8}$ nor any resting place among the shades!

\section{Ešmūñ azar.}

Line 3. It is not safe to build much on the worcls (repeated in line 12) which say that the king was "snatched away by an untimely death". It is indeed very probable that he was comparatively young when he died, and his mother appears to have survived him. But it must always be borne in mind that in the בל עת we have an exact equivalent of

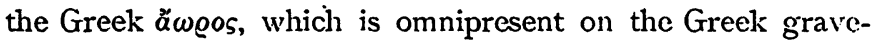
stones of this same region, seemingly irrespective of the age of the departed one. Nearly every death is "untimely" to the bereaved friends and relatives; at any' rate, the probability of a customary formula must be taken into account here. יתם is not "orphan" (as it is usually rendered), but "fatherless", as in Job 24: 9. So also the Arabic and Syriac usage, frequently. אלמת "widow" bears the same relation

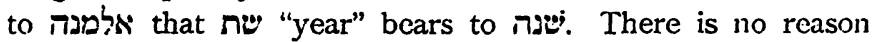
for hesitating over the word.

Line 4. It is absolutely certain that in pinse have the interrogative (= indefinite relative) po and the pronoun

- รุN (see above, on the Byblos inscription). It is equally certain that the $p$ is to be connected with the ' $"$, and not with the preceding sentence; the comparison of line 20 leaves no room for question as to this. Comparing the other occurrences of this customary formula (Byblos 11, Tabnit 3, Nerab I, 5, II, 8, Guzneh 2), the conclusion is obvious that 
the 2 is used here mercly to emphasize the indefinite idea in the $מ$; the usc rescmbling more or less closely that of

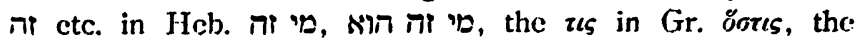
strengthening elements in whoever, whosoever, etc. The origin of the word $p$ is not easy to find. In my Ezra Studies, p. 185 , I. suggested, faute de mieux, the borrowed Greek word $[\varepsilon l] \varkappa \omega i$. The reason for the suggestion was found in the combination of several considerations. Some such word as eixcin "image, likeness, figure", or persona,

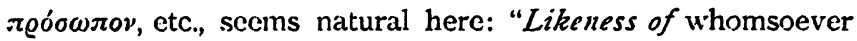
thou art." $\left.{ }^{\prime}\right)$ The principal use of the Syriac oce (= persona and $\pi \varrho \sigma \sigma \omega \pi \circ \nu)$ resembles the use of the ip in this inscription. It is very often used with negatives (like the French personne), but also, in very old usage, in a manner startlingly like the $p$ in these Ešmūn'azar passages, its province being to add strong emphasis. Thus Matt. 5:34 (in the Lewis text, and carried over into the Curetonian) (2) 9, 9 rean "fate has no existence at all";

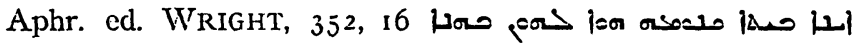
Pats "what sort of house at all had they in this world?" In these cases, and the similar ones which are known (see NöldEkE, Syr. Gramm., $\$ 223$ ), the word likeness would be a fairly good substitute for $x=1 .^{2}$ ) And all the most characteristic use of the Syriac word suggests its origin in some clement $k \bar{o} n+$ the indefinite $m \bar{a}$. As for the probability of such a borrowing from the Greek in the time of Ešmūn'azar, the date (probably the fourth century B.C.) is not too

1) But there is no evidence, so far as 1 know, of a usage in Greek corresponding to that supposed in this passage.

2) It may be added here, that there is no genuine Semitic word "curse". The Rabbinical to which mistaken appeal has been made, is merely a late Jerisis euphemistic substitute for qurbān, one of several characteristic creations of the sort. 
early: But it may be that some better explanation of the ip will be found. ${ }^{2}$ )

Line 6. ברברנם is not a mistake for it is generally regarded. The word is written the same way in both copies of the inscription. The hypothesis of exact reproduction of a faulty original is not admissible, for the two copies do not agree throughout, letter for letter. The original copy was certainly read through carefully by more than one pair of interested eyes, before it was handed over to the engraver. Moreover, the word רַּ "prating" (abundantly attested in O.T. Hebrew) is just the word to expect here. The whole inscription is somewhat hysterically written, from beginning to end. It was probably composed by Am-Aštart, the queen-mother, who is made very prominent in it; and there is some evidence that she had definite reason to apprehend that an attempt would be made to remove the sarcophagus of her son, because of political or family troubles.

It may be that the carving of the inscription in two places is to be explained in this way: As originally composed, it extended only as far as the middle of our line 12. The stone-cutter accordingly engraved it on the end of the sarcophagus. Then Am-Aštart changed her mind, and added to the document an amount almost equal to its original extent. The stone-cutter began with his new material where he had left off before, and added a little more than one line, evidently intending at first to fill the space at the end of the sarcophagus and then continue in some adjoining space. But he decided, or was bidden, to make a better piece of work, in one continuous space; so, breaking off in the middle of a word, he smoothed off the top of the sarcophagus lid and carved the whole inscription there. I do not believe that any skilled workman who had in his hand

1) Borrowing of the Persian gōn, "color, fashion", is also a possibility. to be considered. We know that this was borrowed by the Jews, at least (in the form $; i$ il) as early as Dan. $7: 15$ (my Noles on Aram. of Dan., in loc.). 
this present document of 22 lines would ever have begun to carve in the small (unnecessarily small) space occupied by the fragmentary copy.

Line 9. The part of the imprecation which is contained in this line and the following is generally misunderstood, I think. Cooke, for example, renders: "And may the holy gods deliver them up to a mighty prince who shall rule over them, to cut off that prince or man who shall open this resting-place", etc. But was the regarded as such a terrible man-eater as all this $\left.{ }^{1}\right)$ On the contrary: סגר has just the same meaning here as in line 21 , viz. "exclude" (= give over to destruction). את is the accusative particle, for אית, as in Byblos lines 3 and 7 . לקצתנם is then to be connected with ויסגרנס. The phrase in the second half of line 9 is not logically complete; but all the thought of Am-Aštart was concentrated on "the mighty ruler" (probably the immediate successor of Ešmun' expected to make the attempt to remove the sarcophagus from the royal necropolis. I hope to return to this subject later, in a monograph on the Ešmūn'azar dynastỵ.

\section{Bod - Aštart.}

Inscription I (CIS I 4 ). Whether the king named here is the one named in the other Bod-Aštart inscriptions, is uncertain. An excellent parallel to the name has just been found by the Harvard excavators at Samaria, in the Old Hebrew form בריו (unmistakably written). The first part of the compound is doubtless the noun 7 , "member". The vowel became $\check{o}$ and $\breve{u}$ in the Phoenician pronunciation, just as $\bar{a}$ became $\bar{o}$ and $\bar{u}$.

The latter half of the inscription, from the middle of

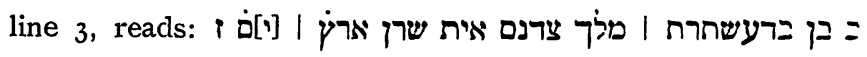

I) Recollect that he is not speaking of "delivering up" a city, or a people, but merely the individuals whom he is cursing. 
לעה לעישתרת. The, at the beginning of the last line is entirely gone, and the dotted letters are missing in part, though the remaining traces are in every case sufficient to make the reading certain. As I have argued elsewherc, ${ }^{\mathrm{I}}$ ) in is "colonnade", the same word as the Aramaic (with prosthetic $N$ ) found in Ezr. 5:3,9 and the Elephantinc papyri, and the Assyrian surinun. Whoever compares the surintmu passages in the inscriptions of Ašurbanapal (KB II 260-263) with the אירוא passage in the Elephantine letter, will see much to suggest that the two words designate the same thing, namely, something which stands in, or belongs to, the outer court of a temple. It stands upright, may be adorned with gold or silver, and (in the case of evidently more extensive than a single column. From the wording of the Bod-Aštart inscription we must conclude that the goddess 'Aštart already possessed a colonnade in one (at least) of the other districts of the great city.

The translation: (Dated) in the month méfa', in the accession-year of the king Bod-'Astart, king of the Sidonians;

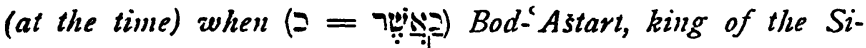
donians, built this Colonnade of the Sea-District to his god, 'Astart.

Inscription II (Répcrtoire, $287-297,300-302,765 \mathrm{ff}$ ). I believe that my original translation in JAOS XXUII (1902), $156-173$, the first publication of any sort which this inscription received, will stand as correct, except in one short passage. A little below the middle of the inscription is found the reading מבנוצרנשר, and the context on both sides makes it evident that the words intended by these letters form a clause by themselves. They might be omitted entirely without any effect either on what precedes or on what follows. ז is obviously the familiar phrase "he who built", and what follows can hardly be anything else than "and "and

1) Especially Ezra Studies, p. 176. 
Siclon". I would suggest that in this short clausc the king is boasting, in genceral terms, of his renown as a buildcr. שר is the denominative verb, "walled", from 7il. "wall". त年 is used absolutely, as often in the Old Testament. The wholc clause is: "He who was a builder, and who walled Sidon." The apparent difficulty in the position of the verb

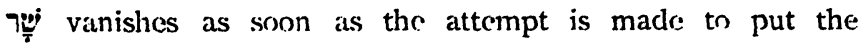
words in any other order. all! Bocl-Aštart did not "build Sidon", he only built (or repaired, or enlarged) the city wall. It was thercfore necessary

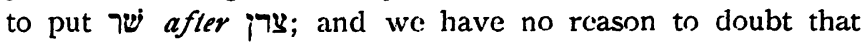
the order of the words was one which was often adopted.

Inscription III (Répertoire, no. 507; IIDZBARSKI, Altsemitiscke Texte p. 20). The beginning reads: מלך ברעישתדת ובן צרקיתנמלך מלך צרנם like Marduk-aplu-iddin, Bēl-šar-ușur, שנזרבן Sin-zēr-bāni (Nērab I), and the host of others, mostly Assyro-Babylonian. That the father of Bod-'Astart did not reign, is shown, I think, by two things: ( $\mathrm{I}$ ) the fact that in the standard long inscription of the Ešmūn temple he does not name his father at all; and (2) the presence of the 1 before $i 2$ in this shorter inscription. (Is it not likely that the 1 belonged to the formula regularly used in such cases? It made it possible for the king to tell who his father was, and at the same time to indicate that the father did not reign.)

The inscription celebrates the building operations of one man only. "He built this house to his god", not, "They built this house to their god."

The stones bearing this shorter form of the inscription were found in the lowest part of the temple wall, and this was undoubtedly the older form of the clocument. The king began by using a very brief formula, in which he gave his father's name. Later on, he changed to the longer and more magniloquent formula, and in this he said nothing about his father. 
The translation: The king Bod-'Astart (woko was also the son of Ședeq-yaton-melek), king of the Sidonians, grandson of king Esminnazar, king of the Sidonians, built this house for his god Esminn, the Holy Lord.

\section{Siloam.}

In line I, after בעור, the probable order of the missing

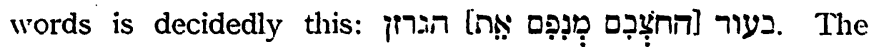
inverse order of the two participles is less likely.

In line 3, the gap after is to be filled as follows:

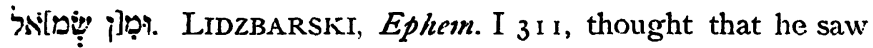
part of a $i$ after $D_{\text {I }}$; and this is by far the most probable letter to expect, under the circumstances. ${ }^{1}$ ) The variation in the manner of writing the pas very likely a literary

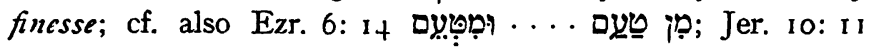

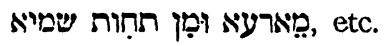

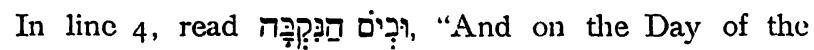
Tunnel". This seems to me the only satisfactory interpretation; supposing the day to have been honored (as it undoubtedly was) by a great celebration, so that it was thereafter known as "the Day of the Tunnel".

\section{Zenjirli. Bar-Rekeb.}

Translate in lines 6 f.: "My Lord Tiglathpilescr placed me upon the throne of my father, and in my father's palace, laboring more (zealously) than any one (of my predecessors had labored)." This agrecs with what is said below.

Translate in lines $16 \mathrm{f}$.: "And through me (came) a prosperity which was not enjoyed by (literally, did not belong to) my fathers, the kings of Sam'al."

1) J have no doubt that the word ה7i in this line moans "fissure", but no one of the proposed etymologies secms to me to hare even the smallest plausibility. 
The word which is divided by the end of line 17 is

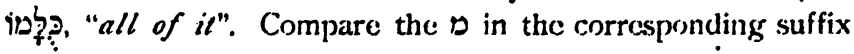
in Hebrew, Is. $44: 1.5$ being perhaps the best single example. Trunslate: "It is a house, all of which is for them" (viz. the ancestors of Bar-R(keb).

\section{Nërab II.}

The interpretation which renders מחזה אנה in line 5 by "What do I see?" scems to me not only too fanciful, but also logically objectionable. We should certainly expect in that case "What did I sec?", especially as the verbs which follow are all in the perfect tense. Moreover, the verb ins in line 4, immediately correlated with מחוה אנה, also expresses past time. It seems to me very much more probable that we have here a passive participle of the haf $\mathrm{c} e \mathrm{l}$ stem (i. e., presumably, a lof' $a l$ ), such participles being very often used in speaking of actions or events completed in past time. Translate: "On the day of my death my mouth was not restrained from speaking, and with my eyes I was permitted to see. Children of the fourth generation wept

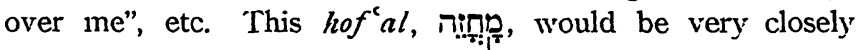
related to the haf'el הריאני (Měa', line 4), "caused me to see (my desire)"; cf. also החוין in lines $16 \mathrm{f}$. of the Sachau papyrus from Elephantine.

In lines 7 f., the passage למען לאחרה ל ההנם ארצתי must be rendered: "In order that my coffin may not be plundered(?) by another." ארצתי is certainly the subject of the verb, which may be either passive or intransitive péal. ל of the agent. With the "another" compare the inscription I.IDzBARSKI, Handb. 484,3 , line 3 , which is a perfect parallel.

\section{Guzneh.}

The text of this old Aramaic boundary stone from $\mathrm{Ci}$ licia, published by MONTGONERY in the JAOS XXVIII (1907), 164 ff., reads as follows: 


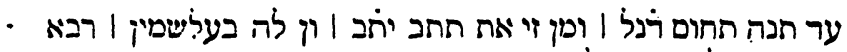

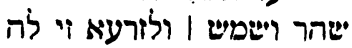

MONTGOMERY's reading differed from this at the end of the second line and the beginning of the third. After

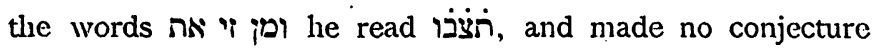
for the last letters of the line. Line 3 he began with $j$, rendering: "And whoever thou art who wilt [destroy, overwhelm] him Beél Šamên", etc.

I have examined carefully, with lighting from every side, the plaster cast made from a wax impression of the stone. The readings which I have given above are, I think, quite certain, with the exception of the $\Omega$ in $ת$; and even there, $\Omega$ is the only letter which the traces suggest.

I translate: Thus far the boundary of DNL. Whosocver thou art who destroyest (it), - Baialsamēn the great, Sahar, and Šamas, shall destroy him and his secd!

Point (تبّ, תבد) which is used, for example, in Sura 11 I of the Koran, where Mohammed, in his fierce imprecation upon Abu Lahab, says: "May he utterly perish!"? The verb is otherwise known only in Arabic.

\section{The Abydos Lion-weight.}

(CIS II 108.)

The reading appears to be:

\section{אסEjן לקבל סהריא זי בספט}

The first word is generally read אספל (which is possible), and has often been connected with the problematic which occurs seven times in the Aramaic of Ezra. But the word in Ezra never means "exact" or "exactly" (see my

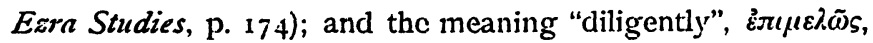
studiose, will hardly do for the inscription on this weight. 
The first word is probably a proper name, telling to whom the lion belonged, as in case of the most of the wcights of this kind; see G. F. HILL, Handbook of Greck and Roman Coins, p. 29. The word ארי is probably "staters"; cf. the Lewis Syriac of Matt. 17:27, where for

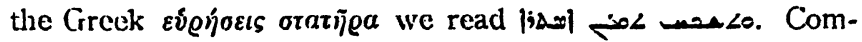
parc no. 9 of the weights described by HILL, loc. cit.: "Onethird manah in shekels", etc. 